\title{
Habitat use and selection by Red-crowned Crane Grus japonensis in winter in Yancheng Biosphere Reserve, China
}

\author{
ZHIJUN MA*, ZIJIAN WANG \& HONGXIAO TANG \\ State Key Laboratory of Environmental Aquatic Chemistry, Research Center for Eco-Environmental Sciences, \\ Chinese Academy of Sciences, PO Box 2871, Beijing, 100085, People's Republic of China
}

\begin{abstract}
We report the distribution and habitat selection by the Red-crowned Crane Grus japonensis in winter in the Yancheng Biosphere Reserve, China. Including original wetlands and artificial habitats, six types of habitat are used by the species: saltworks (salinas), fish ponds, reed beds, Wormwood Artemisia halodendron beaches, tidal grasslands and wheat fields. We compared the habitat availability with habitat use in each type. In winter, Red-crowned Crane preferentially used tidal grasslands and fish ponds. Saltworks, Wormwood beaches and wheat fields were avoided. The distribution of Red-crowned Crane in different types of habitat changed with the distribution of freshwater and with human activities.
\end{abstract}

The Red-crowned Crane Grus japonensis is one of the most vulnerable bird species in the world (Collar et al. 1994; Species Survival Commission/International Union for Conservation of Nature and Natural Resources 1994). The breeding areas of the birds are in Hokkaido, Japan, North Korea, South Korea, eastern Russia, Mongolia, and the northeast and the eastern coasts of China. The total number of individuals in the world in 1994 was about 1050-1200 (Collar et al. 1994). The Yancheng Biosphere Reserve in Jiangsu Province of China is the species' largest wintering site. Since 1983 when the reserve was founded, the number of Red-crowned Cranes wintering there increased to 876 in 1993 (Han \& Gretchen 1995) and, by the winter of 1996, it had reached 1020, which is half of the world total. The Red-crowned Cranes' main habitat was original wetlands (Ding \& Zhou 1982) but intensive exploitation of tidal lands has destroyed much original wetland. However, artificial wetlands and other habitats have been formed in the course of this development. A knowledge of the habitat use and selection by the Red-crowned Crane can help develop management strategies for this threatened species.

\section{STUDY AREA}

Yancheng Biosphere Reserve is in the centre of the eastern coast of China, between $32^{\circ} 34^{\prime} \mathrm{N}$ and $34^{\circ} 28^{\prime} \mathrm{N}$,

${ }^{*}$ Corresponding author.

Email: zhijun@mail.rcees.ac.cn $119^{\circ} 48^{\prime} \mathrm{E}$ and $120^{\circ} 56^{\prime} \mathrm{E}$. The reserve consists of coastal beaches across five counties of Yancheng city. The coastline in the reserve is $584 \mathrm{~km}$ long and the total area is about $4530 \mathrm{~km}^{2}$. The major objective of the reserve is to protect the Red-crowned Crane and other bird species, as well as their habitats. The reserve is a typical coastal wetland ecosystem and is the first reserve of a beach strand type in China. In 1992, It was international recognized by UNESCO as a Biosphere Reserve (Han \& Gretchen 1995).

Most of the reserve consists of tidal land with abundant plants and invertebrates. In recent years, some tidal lands have been changed to other land types, such as fish ponds, saltworks and agricultural fields. This has seriously changed the conditions for the Red-crowned Crane.

Every year in October, Red-crowned Cranes migrate here from their breeding grounds and stay until March. In our study, the number and distribution of Redcrowned Cranes in the Yancheng Biosphere Reserve was surveyed between November and January in 1995-97 when their numbers and habitats were stable. To cover the large investigation area, three investigation groups worked simultaneously.

\section{RESULTS}

\section{Habitat distribution for Red-crowned Crane}

The habitats used by Red-crowned Cranes included not only the original wetlands, but also man-made land 


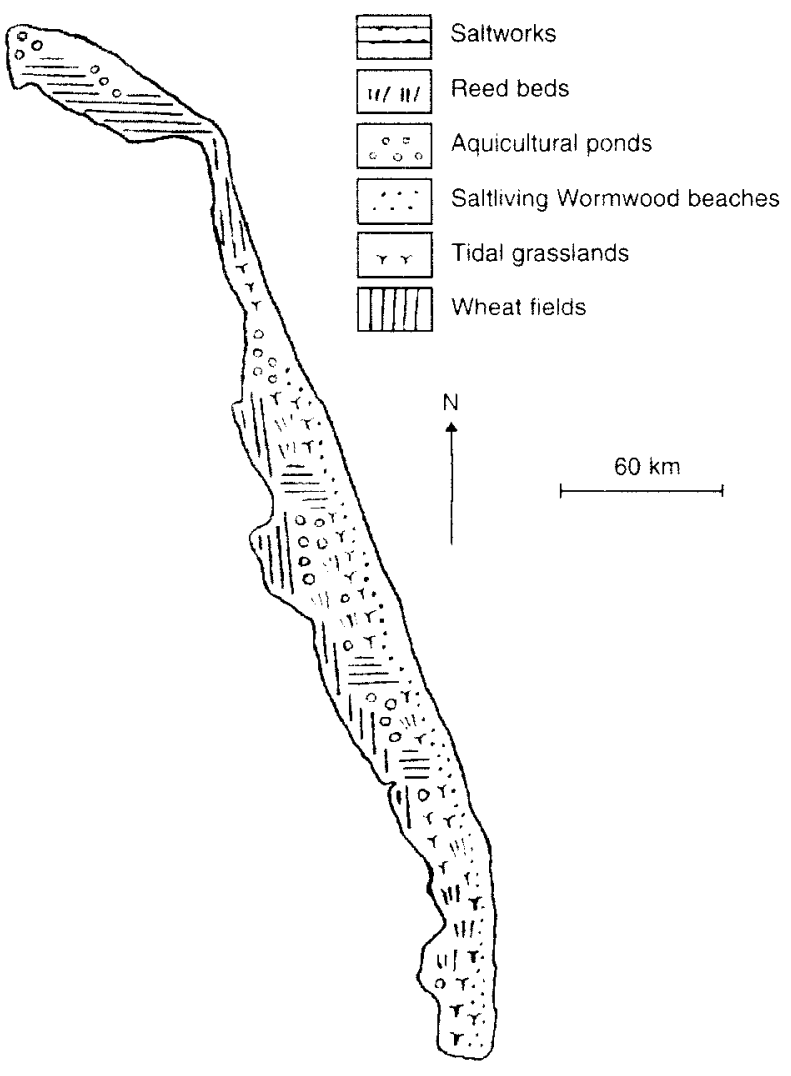

Figure 1. Distribution of habitat types in the Yancheng Biosphere Reserve.

types. Our study found that Red-crowned Cranes distributed mainly on six types of habitat. The characteristic of habitats are listed below and their distribution is shown in Figure 1.

\section{Saltworks (salinas)}

Saltworks are artificial wetlands. Most saltworks are lecated at the northern part of the reserve. The water quality, biomass and biodiversity in primary saltworks are similar to those observed in sea-water. Redcrowned Cranes feed on snails or nereid worms on beaches or in shallow water. While the primary saltworks are suitable habitats for Red-crowned Crane, their value declines during the salt concentration process.

\section{Fish ponds}

Fish ponds are artificial habitats used to raise fish or shrimps in shallow water. This provides abundant food resources for Red-crowned Crane. In winter, the water is drained from the ponds to allow harvesting. This action also provides food for Red-crowned Cranes and other waterbirds.

\section{Reed beds}

The reed beds include Reed Phragmites communis growing both in natural conditions and planted by man. The original reed beds are in lowland or at river mouths where there is shallow water. The artificial reed beds were formed by enclosing and irrigating tidal lands and cultivating reeds. The reeds are harvested in winter

\section{Wormwood beaches}

The Wormwood community, which contains Common Seepweed Suaeda glauca, is an intermediate stage in the community succession of coastal vegetation. The salt content of the soil is high. Most Wormwood beaches are in the centre and southern parts of the reserve and have not been reclaimed. With the accumulation of silt, the coastline grows outwards and the former tidal land becomes further from the sea. Consequently, the salt content of the soil declines slowly. Wormwood is a halophyte and, with the decreasing salt content of the soil, it is gradually replaced by Chinese Aeluropus Aeluropus littoralis.

\section{Tidal grasslands}

This is one of the important types of original wetlands on the reserve. The tidal grasslands are a climax regetation type on salty soil. The abundance and species diversity on this type of land are rich. In lowland and river delta areas, the dominant vegetation is marshland, containing Yagara Bulrush Scirpus yagara, Scabrousleaf Sedge Carex scabrifolia and the Flatstalk Bulrush Scirpus planiculmis. In dry tidal lands, the dominant plant species is Lalang Grass Imperate cylindrica var. major and Chinese Aeluropus.

\section{Wheat fields}

Wheat fields are located at the inland edge of the reserve. The salt content of the soil declines as the distance from the sea increases. Farmers have changed tidal lands to wheat fields for agricultural production, and plant wheat in autumn. Sometimes Red-crowned Cranes feed on wheat seed in fields.

Among these habitats, the Wormwood beach is the only one retaining the characteristics of original wetland. Others have been subjected to the influences of human activities. Table 1 gives the characteristics of the six main habitat types.

\section{Habitat selection of Red-crowned Crane}

The numbers of Red-crowned Crane in different habitats and different wintering periods in 1995-97 are listed in Table 2. The few cranes in other habitats are 
Table 1. Characteristics of the six types of habitat on Yancheng Biosphere Reserve (average for 1995-97).

\begin{tabular}{|c|c|c|c|c|c|c|}
\hline \multirow[b]{2}{*}{ Characteristic } & \multicolumn{5}{|c|}{ Habitat type } & \multirow[b]{2}{*}{ Wheat fields } \\
\hline & Saltworks & $\begin{array}{l}\text { Fish } \\
\text { ponds }\end{array}$ & Reed beds & $\begin{array}{l}\text { Wormwood } \\
\text { beaches }\end{array}$ & $\begin{array}{c}\text { Tidal } \\
\text { grasslands }\end{array}$ & \\
\hline Area $\left(\mathrm{km}^{2}\right)$ & 324.5 & 251.2 & 107.0 & 266.0 & 139.9 & 287.3 \\
\hline Biomass of zoobenthos $\left(\mathrm{g} \mathrm{m}^{-3}\right)$ & 241 & 194 & 379 & 378 & 362 & - \\
\hline Degree of plant cover (\%) & - & - & $70-90$ & $30-70$ & $40-90$ & - \\
\hline Dominant plants & - & Reed & Reed & $\begin{array}{l}\text { Wormwood, } \\
\text { Chinese Aeluropus, } \\
\text { Common Seepweed }\end{array}$ & $\begin{array}{c}\text { Lalang Grass, } \\
\text { Chinese Aeluropus }\end{array}$ & Wheat \\
\hline Dominant animals & $\begin{array}{c}\text { Snail, } \\
\text { nereid worms }\end{array}$ & Fish, shrimp & Crab & Crab, snail & Crab & - \\
\hline
\end{tabular}

not included. The distribution of Red-crowned Crane in the different habitats and at different periods of the winter are compared.

Habitat selection was analysed by comparing expected and observed habitat use by the Redcrowned Crane (Neu et al. 1974). In Table 3, the relative habitat use by Red-crowned Crane (proportion of numbers in each habitat type) is compared with the relative habitat availability within the study area. The tidal grasslands were positively selected by Red-crowned Crane $(P<0.01)$ and at no time showed avoidance. Saltworks and wheat fields were avoided at all times. Wormwood beaches were also avoided except in December 1996. Red-crowned Crane showed no selection for reed beds in winter.

We used the Friedman test to compare the habitat use in the different periods (Table 4). The habitat use for Red-crowned Crane was not constant. The selection of fish ponds changed in different periods from 1995-97. Compared with December 1995 and January 1996, the numbers of cranes in wheat fields increased markedly in December 1996 and January

Table 2. The mean number of Red-crowned Cranes in different habitats and in wintering months of 1995-97 in Yancheng Biosphere Reserve.

\begin{tabular}{lccccccc}
\hline & \multicolumn{9}{c}{ Number of cranes in } \\
\cline { 2 - 6 } Month & Saltworks & $\begin{array}{c}\text { Fish } \\
\text { ponds }\end{array}$ & Reed beds & $\begin{array}{c}\text { Wormwood } \\
\text { beaches }\end{array}$ & $\begin{array}{c}\text { Tidal } \\
\text { grasslands }\end{array}$ & Wheat fields & Total \\
Dec 1995 & 35 & 127 & 66 & 43 & 454 & 7 & 732 \\
Jan 1996 & 35 & 232 & 89 & 36 & 385 & 3 & 780 \\
Dec 1996 & 27 & 3 & 69 & 202 & 603 & 95 & 999 \\
Jan 1997 & 27 & 53 & 72 & 146 & 557 & 95 & 950 \\
\hline
\end{tabular}

Table 3. Habitat selection by Red-crowned Crane in Yancheng Biosphere Reserve in 1995-97.

\begin{tabular}{|c|c|c|c|c|c|c|}
\hline & \multicolumn{6}{|c|}{ Frequency of use $(\%)$ of } \\
\hline & Saltworks & $\begin{array}{l}\text { Fish } \\
\text { ponds }\end{array}$ & $\begin{array}{l}\text { Reed } \\
\text { beds }\end{array}$ & $\begin{array}{c}\text { Wormwood } \\
\text { beaches }\end{array}$ & $\begin{array}{l}\text { Tidal } \\
\text { grasslands }\end{array}$ & Wheat fields \\
\hline Expected & 23.6 & 18.2 & 7.8 & 19.3 & 10.2 & 20.9 \\
\hline Observed Dec 1995 & $4.8\left(^{* \star}\right)$ & 17.3 & 9.0 & $5.9\left(^{\star \star}\right)$ & $62.0^{\star \star}$ & $1.0\left(^{\star \star}\right)$ \\
\hline Observed Jan 1996 & $\left.4.5^{(* \star}\right)$ & $29.7^{\star \star}$ & 11.4 & $4.6\left(^{\star \star}\right)$ & $49.4^{\star *}$ & $0.4\left(^{\star *}\right)$ \\
\hline Observed Dec 1996 & $2.7\left(^{\star \star}\right)$ & $0.3\left(^{\star \star}\right)$ & 6.9 & 20.2 & $60.4^{\star \star}$ & $9.5\left(^{* *}\right)$ \\
\hline Observed Jan 1997 & $2.8\left(^{\star \star}\right)$ & $5.6\left(^{\star \star}\right)$ & 7.7 & $15.4\left(^{*}\right)$ & $58.6^{\star \star}$ & $10.0\left(^{* *}\right)$ \\
\hline
\end{tabular}

Relative observed habitat use (\%) by the Red-crowned Crane in winter in 1995-1996 and 1996-1997 compared with the relative habitat availability $(\%)$ in the study area (expected use). Differences between observed (proportions of number on every habitat type) and expected frequencies (proportions of every habitat type in the area) were tested using Bonferroni simultaneous confidence intervals analysis. ${ }^{*} P<0.05,{ }^{* \star} P<0.01$. Parentheses indicate negative selection. 
Table 4. The difference of habitat use by Red-crowned Crane in winter periods. The differences were tested using Friedman tests.

\begin{tabular}{|c|c|c|c|c|c|c|}
\hline \multirow[b]{2}{*}{ Winter period } & \multirow[b]{2}{*}{ Saltworks } & \multicolumn{3}{|c|}{ Habitat use of } & \multirow[b]{2}{*}{$\begin{array}{c}\text { Tidal } \\
\text { grasslands }\end{array}$} & \multirow[b]{2}{*}{ Wheat fields } \\
\hline & & $\begin{array}{l}\text { Fish } \\
\text { ponds }\end{array}$ & Reed beds & $\begin{array}{c}\text { Wormwood } \\
\text { beaches }\end{array}$ & & \\
\hline Dec 1995 and Jan 1996 & 0.8 & $32.0^{\star *}$ & 2.2 & 1.7 & $24.4^{\star \star}$ & 2.4 \\
\hline Dec 1996 and Jan 1997 & 1.0 & $48.0^{\star \star}$ & 2.3 & $8.0^{\star *}$ & 1.7 & 1.1 \\
\hline Dec 1995 and Dec 1996 & $5.1^{\star}$ & $176.3^{\star \star}$ & 2.4 & $71.2^{* *}$ & 1.2 & $55.4^{* *}$ \\
\hline Jan 1996 and Jan 1997 & 2.1 & $180.3^{* *}$ & $8.5^{\star \star}$ & $53.5^{\star \star}$ & $14.8^{\star \star}$ & $74.3^{\star \star}$ \\
\hline
\end{tabular}

${ }^{*} P<0.05{ }^{* *} P<0.01$

$1997\left(\chi^{2}=55.4,74.3, P<0.001\right)$. The utilization of saltworks did not change much between the two years, and the same applied to reed beds, except between January 1996 and January 1997.

\section{DISCUSSION}

Our study showed that Red-crowned Crane did not use the available habitat types in proportion to their availability. This finding is similar to that found for other species, including Dunnock Prunella modularis (Tuomenpuro 1989), Brown Kiwi Apteryx australis (Barbara \& Michael 1995) and Nutcracker Nucifraga caryocatactes (Rolando 1996). Our study areas consisted of the main land types on the reserve, not only the original wetlands (Wormwood beaches, tidal grasslands), but also man-modified habitats (saltworks, wheat fields, fish ponds). During the winter, Redcrowned Crane preferred regions of tidal grasslands; they held about $50 \%$ of the Red-crowned Crane in about $10 \%$ of the total area. In previous years, tidal grasslands had always been the main habitats for Redcrowned Cranes in winter (Lu \& Zhow 1990, Yan 1991, Lu 1995), presumably because they provide good protection and food resources.

In winter, there are obvious differences in the selection of fish ponds by Red-crowned Cranes. This is caused by human activities. Fishermen drain the water in the ponds at the end of December to catch fish; the other aquatic animals exposed in the shallow water are taken by Red-crowned Cranes. This temporary preference caused a decrease in the number of Red-crowned Cranes in other habitats.

No significant differences were found in the use of saltworks between different periods of the winter, as also found by Tao (1984) and Lu (1989) in 1982-88. This is probably caused by the large area of saltworks and the progressive decline in human activity during the course of salt production.

In winter, there was no selection of reed beds by
Red-crowned Crane. It is a stable habitat for Redcrowned Crane through the two winters $\left(\chi^{2}{ }_{1}=2.2\right.$, $2.3,2.4, \mathrm{~ns}$ ), except for the difference between January 1996 and January 1997. The height of reed is about 1.4-2.0 $\mathrm{m}$ and it provides good protection for Redcrowned Cranes. After the reeds are harvested, this tidal land is exposed and attracts Red-crowned Cranes searching for food. In addition, most of the reed beds are located on lowland or at river mouths where there is abundant freshwater which provides drinking water for Red-crowned Cranes when the season is dry. Therefore, the reed beds are stable habitat for Redcrowned Cranes although the influence of human activity can be serious on occasions.

Compared with 1995-96, the distribution of Redcrowned Crane changed obviously in the winter of 1996-97, probably resulting from differences in the rainfall. The annual rainfall was $740 \mathrm{~mm}$ in the reserve in 1995 (the average annual rainfall is $1000 \mathrm{~mm}$ ). The dry condition caused increasing numbers of Redcrowned Cranes to use fish ponds for food and drinking water. In 1996, the annual rainfall was 400 $\mathrm{mm}$ more than that in 1995. Abundant rainfall produced good conditions for plant growth on tidal lands, and many pools were also formed on tidal grasslands and the Wormwood beaches. This provided a rich source of food and drinking water for Redcrowned Cranes and many were attracted.

In the winter of 1995, food poisoning was caused by agrochemicals and pesticides used in the wheat fields. More than 20 Red-crowned Cranes were poisoned and seven died. Reserve managers and the local government have now paid more attention to this and the use of agrochemical and pesticides was forbidden in 1996. About 100 Red-crowned Cranes frequently fed in the wheat fields and this became one of the main habitats for Red-crowned Cranes as a result of protection.

Wheat fields are a new type of habitat on the reserve for the Red-crowned Crane: the birds were not recorded there in earlier years (Lu 1988, Wang 1991, 
Yan 1991). This is similar to the situation in Japan where Red-crowned Cranes lived in farm fields after the disappearance of wetlands (Johnsgard 1983). The habitats used by Red-crowned Cranes are diverse in Yancheng Biosphere Reserve and our study shows that the Red-crowned Crane is adapting to new environments arising from economic development. More attention should be given to the protection of Redcrowned Crane, both by the reserve managers and local government, so that the conflict between nature protection and economic development can be co-ordinated.

We are grateful for the support of Yancheng nature reserve, China which provided information and documents for this work. We also thank the Chinese National Committee for Man and Biosphere (MAB) programme for their support.

\section{REFERENCES}

Barbara, T. \& Michael, T. 1995. Habitat use and selectivity by the Brown Kiwi Apteryx australis Mantelli in a patchy environment. Auk 112: 680-689.

Byers, R.C., Steinhorst, R.K. \& Krausman, P.R. 1984. Clarification of a technique for analysis of utilization-availability data. J. Wildl. Mgmt. 48: 1050-1053

Collar, N. J., Crosby M. J. \& Stattersfield A. J.. 1994. Birds to Watch. 2: The World List of Threatened Birds. Cambridge, UK: Birdllife International (BirdLife Conservation Series No. 4).

Ding, W.N. \& Zhou, F.Z. 1982. The wintering distribution of cranes in China. Chin. J. Zool. 17(6): 13-14.
Han, N.Y. \& Gretchen, J. de Boer. 1995. China's Biosphere Reserves. Beijing: Chinese National Committee for MAB.

Johnsgard, P. A. 1983. Cranes of the World. Bloomington: Indiana University.

LU, S.C. \& Zhou, S.E. 1990. Inquiry of distribution tendency of Redcrowned Crane in the coast of Yancheng. Chin. Nature Magazine 2: 101-103.

Lu, S.C. 1988. The number and distribution of Red-crowned Crane in winter in Yancheng seaside. Sichuan Anim. 4: 41-42.

Lu, S.C. 1989. The distribution of Red-crowned Crane in Yancheng Reserve. Chinese Wild. 1: 19-21.

Lu, S.C. 1995. Protecting precious and rare animals in sea shore and economic development in Yancheng, Jiangsu province. China's Biosphere Reserve 4: 13-15.

Rolando, A. 1996. Home range and habitat selection by the Nutcracker Nucifraga caryocatactes during autumn in the Alps. Ibis 138: 384-390.

Species Survival Commission/International Union for Conservation of Nature and Natural Resources. 1994. IUCN Red List Categories. Gland, Switzerland: IUCN.

Tao, D.W. 1984. The wintering site of Red-crowned Crane in salt tidal lands of Xiangshui county. Chinese Wildl. 2: 20-21.

Tuomenpuro, J. 1989. Habitat preferences and territory size of the Dunnock Prunella modularis in southern Finland. Ornis Fenn. 66: 133-141.

Wang, H. 1991. Annual Report from Yancheng National Nature Reserve. Jiangsu, China: Yancheng Wetland and Waterbird Conservation Center, Management Division of Yancheng NNR.

Yan, F.T. 1991. The number distribution and ecology research of wintering Red-crowned Crane in tidal lands of Yancheng. Chin J. Zool. 2: 34-36.

Received 24 March 1997; revision accepted 19 September 1997 